Article

\title{
The Rise of Fascist Formations in Chile and in the World
}

\section{Rene Leal}

Departamento de Publicidad e Imagen, Universidad de Santiago de Chile, Santiago 8320000, Chile; rene.leal@usach.cl

Received: 12 November 2020; Accepted: 11 December 2020; Published: 14 December 2020

\begin{abstract}
This essay examines the contemporary crisis in Chile in the context of the rise of the global far right. What led to the popular uprising in Chile in October 2019, and what forces are represented by its violent state repression? Fascist formations are currently developing in various nations; Umberto Eco's concept of Ur-Fascism is useful in tracing the range of fascisms and their characteristics. These include populism, nationalism, racism, and syncretic traditionalism. In Chile, the racism of the far right is directed against its indigenous people more than immigrants. The 'unfinished business' of capitalist development here is the historical background of the oppressive relationship established by the 'West' over the 'Rest', in Stuart Hall's terms. Fascism emerges periodically, temporarily resolving crises of accumulation through runaway activity of capital, entailing suppression of the working class and its organization. Neoliberalism has been the latest form of this exacerbation, but as its contradictions have intensified, its ideology no longer manages to mask the exploitation and secure consent. Neoliberalism, trialed in Chile after the 1973 coup under United States hegemony, became globally entrenched following the collapse of Soviet-bloc socialism and the ensuing weaknesses and crises of the organized left and the decay of social democracy. Neoliberal ideology has sustained capital at the same time as neoliberal policies have augmented the precarity of subordinated classes. As this becomes apparent with the sharpening of contradictions, the anachronistic relationship between liberalism and democracy has been deeply damaged. It becomes clear that capital's profitability is privileged over the needs and wishes of the people. In this framework, to explore the rise and meaning of fascism is thus to examine the condition and possibilities of modernity and its limits. Modernity is besieged by pressurs coming from premodern esentialist conceptions of the world and also by the postmodernist's view of chaos and fragmentation of a spontaneous social order; neoliberalism becomes compatible with both. Fascism lacks a coherence, but is anchored emotionally to archetypal foundations. Its very eclecticism embraces a wide range of anti-socialist and anti-capitalist discourses, which have enabled it to take root in mass movements. Its ideological resolution of the contradiction between capital and labor is temporary: the intensifying of capital accumulation activates its opposition, to the point where the distorting effect of ideology is unveiled and contradictions appear as class struggle. The longstanding imposition of neoliberalism in Chile, and the runaway activity of capital which it supported have has been rejected and partially defeated by the October 2019 rebellion in Chile. The far right has backed down but has not been defeated. The plebiscite of 25 October 2020 has delivered the people's verdict on neoliberalism. However, in the different global and national circumstances of 2021, the fascists still among us may yet seek to reassert the order that they sought in 1973.
\end{abstract}

Keywords: west and 'rest'; fascism; neoliberalism; ideology; democracy; modernity; class struggle 


\section{Introduction}

This article interrogates the growth of the extreme right with particular reference to Chile, drawing upon historical, sociological and philosopical debates ${ }^{1}$. It traces the background of this political phenomenon using the conceptual map of Stuart Hall's (2013) delineation of the 'West' and the 'Rest', considering the hegemony of neoliberalism in current global capitalism and the relevance of its ideology in the emergence of the far right. Among the 'Rest' who live in Latin America, and in particular in Chile, fascism is no stranger: Chile was a battlefield falling to the dictatorship of the far-right Pinochet regime, installed in the coup of 1973. This entrenched, for several generations, what became known as neoliberalism, and the country served as a testing field for its global pioneering. It is important to recall that this hegemony was never uncontested; the forward march of the far-right is not inexorable. The Pinochet regime was replaced by a liberal democracy, but the political-cultural and indeed legal-constitutional baggage that it bequeathed is now finally under serious siege after nearly five decades of 'war of position'. At stake is the hegemony of neoliberalism, whose ideology no longer elicits mass consent or even acquiescence, in the era of austerity ushered in by the global financial crisis. Chile could once more be at the international forefront of the fate of the right wing, this time as the site of its reversal.

The paper begins with a historical background from the formation of the 'West' and the 'Rest', then shows its effects in Latin America and the 'stories' of the state and political formations in what is now Chile. With this context, discussions of the rise of the far right in Latin America and globally will be considered. After this, Umberto Eco's philosophical reflections about fascism will be presented, along with Michael Löwy's hypothesis about the rise of the far right. Finally, the rise of class struggle in Chile in the rebellion of the people in 2019, will be presented. These multifaceted social actions revealed the ideological character of neoliberalism and the unequal and inhuman consequences of the acute capitalist accumulation for the Chilean people. Neoliberalism is facing a crisis of hegemony, in which the far right has backed down, but has not been definitively defeated.

\section{The Formation of the 'West' and the 'Rest' and Its Effects in Latin America}

For Stuart Hall, the 'West' refers to the type of society recognized as

developed, industrialized, urbanized, capitalist, secular and modern. Such societies emerged in a particular historical period - roughly during the sixteenth century after the Middle Ages and the fall of feudalism... Today, any society that shares these features, wherever it exists on the geographical map, can be branded as belonging to "the West". The meaning of this term is, therefore, virtually identical to that of the word «modern».

(Hall 2013, p. 51)

The emergence of the West, argues Hall, is also a global phenomenon. Indeed, as Roberts observes, "modern history can be defined as the martial advance toward the era dominated by the West" (Roberts in Hall 2013, p. 53). This historical trajectory entailed that "the West and the Rest became two sides of the same coin; what each one is today, and what the terms we use to describe them mean, depend on the relationships that were established between them from a long time ago" (Hall 2013, p. 53). Consequently, the identity and uniqueness of the West was, to a large extent, the result of the articulation and comparison of Europe of itself with other "non-western" societies, the 'Rest', very different in their histories, ecologies, development models and cultures from those of the European model. The difference between these other societies and the cultures of the West was the standard by

1 This essay was informed by the work of the Research Group of 'Analisis de Coyuntura y Tendencias Politicas' (Analysis of Political Conjuncture and Tendencies), whose focus was to examine the first two years of the current Government of the Right and the October People's Rebellion, researches of which I am co-author (see Azocar et al. 2019, 2020). 
which the achievement of the West was measured. It is in the context of these relationships that the idea of 'the West' took shape and meaning (Hall 2013, p. 53).

Europe's identity, reflected in the idea and represented as the 'West', was not a result of an administrative or formal institutional unity. This was formed, according to Hall, through a long period of time, from the end of the middle ages. Europe's identity as 'the West', emerged as an identity in opposition to a strong Islamic challenge, which became a key factor in the consolidation of Western, European identity. In addition, this identity was reinforced during the periods of exploration, conquest, and colonization, which was, at the end consolidated for the most powerful sense of social identity, Christianity (Hall 2013).

Christianity consolidated Europe's identity and the concept of the 'West' (Hall 2013, p. 70)'. This normative identity crossed state, ethnic, class and gender lines and was a trascendental element for the universalization of Catholicism and the influence of the 'West' in the 'rest' of the world.

This will be also particularly useful to understand the formation of the 'rest' in Latin America and in Chile, in particular class, gender and state formations. In Chile, is it crucial to understanding the political formations of parties and movements: right, left and, especially fascist formations. Furthermore, the centrality of Europe as the 'West' and the representation of the 'Rest' arose, to a great extent, from a non-innocent European discursive formation, which Foucault called 'regime of truth' (Foucault in Hall 2013, p. 78).

Using the discursive device, in the case of the East, a good example of the representation of the 'rest' as 'the other', is provided by Edward Said in his outstanding work, Orientalism. Said argued that it is necessary to examine Orientalism as a discourse in order to understand the systematic discipline through which European culture has been able to manipulate and lead the East from a political, sociological, military, ideological, scientific and imaginary point of view since the post-Enlightenment period (Said cited in Hall 2013, p. 79). In this way, the West's hegemony becomes so overwhelming that the East is not a subject of which people have freedom of thought or action (Hall 2013, p. 79).

It is interesting to note that ideology, as Marx understood it, was arising —as a cause and effect—of the constitution of this unequal and hierachical relationship that the West built with the 'Rest', in which the former became hegemonic. This happened during the passage from feudalism to capitalism and the emergence of the bourgeosie, from which its political representation, the 'right', would later emerge. The concept of ideology is crucial in dealing with a contemporary phenomenon at the heart of late capitalism: the rise of fascism. This is so because Marx's concept of ideology, as "a specific kind of distortion which conceals contradictions and stems from their existence" (Larraín 1983, p. 30), comprehends how the interests of the ruling class can be made to appear as the interests of 'the people' or of 'the nation', which are representations typical of the right wing and indispensable to fascism, in Chile and in the world.

\section{Particularities of Capitalism in Latin America: Modernity and Identity in Dispute}

It is necessary, to briefly refer to the specificities of capitalism and modernity in Latin America, molded by the articulation of modes of production between between the 'West' and the 'Rest' ${ }^{2}$. One of these specificities lies in the relationship between the modern concepts of 'autonomy' and 'control' which as Larraín (2005) argues, are manifested in a different way from Europe.

One of the greatest cultural traditions in Latin America highlighted by Larraín is "its excessive centralism, legacy of its colonial past, in addition to the monopoly held by the Catholic religion, the export economy of raw materials, limited, promoted and controlled by the State, which added to

2 The concept of articulation of modes of production as used here has proved to be an effective theoretical and methodological tool to understand the clash between the European modes and the American ones. See Pierre Philippe Rey (Larraín 1989, p. 81) and Leal (1999). 
authoritarian political power, have defined the cultural features that, in one way or another, have persisted to this day" (Larraín quoted in Aranguiz 2007, p. 5).

In Latin America, "the autonomy process did not come from the colonies themselves. Also there was no rationalization of production and no scientific methods were introduced according to economic demands. This meant that greater importance has been attached to how to solve the problem of self-government rather than concern over the expansion of rational control" (Aranguiz 2007, p. 5). Hence, "this superiority of one imaginary meaning over another (of autonomy over control), [does not mean, according to Larraín], that there has been no modernity in Latin America, but that it was institutionalized in a different way than it happened in Europe and in the United States" (Aranguiz 2007, p. 5). This has been, and continues to be,

the great "weakness" that afflicts Latin America, and which has also meant its stigmatization as a continent incapable of introducing technological advances as well as worrying about its governability. In other words, seeking a balance between economic development and political and institutional stability, which is not always possible to obtain in nations that are in a phase of economic underdevelopment, also marked by ethnic disputes, territorial problems and the ever threatening irruption of military forces.

(Aranguiz 2007, p. 5)

It should be added that this was the historical-cultural framework in which the labor movement developed from the end of the 19th century, which had a long and painful birth at the beginning of the 20th century. The nascent proletariat was the product of a history originating in the servile relations of the rural cycle of the hacienda that were deployed since the conquest of Mapuche ${ }^{3}$ land in 1541, in the form of encomiendas ${ }^{4}$, and that continued during the colonial period until the second half of the 19th century and indeed lasting until the 1960s in the central-south part of the country (Leal 1999).

Emigration of peons and peasants to the north, escaping the abusive, exploitative, and criminal treatment of landowners, contributed to the development of the nascent nitrate mining industry, with the first features of an incipient and exploitative wage labor. Meanwhile in the south, servile relations continued on the latifundia. Modernity barely made its way into what is now Chile, where at the same time the largest body of native people in the territory, the Mapuche people, were stripped of their land. They fought a war for more than 350 years against the Spanish empire, which they defeated. This led to their recognition by the Crown as a nation from the Bio Bio river to the south at the end of the 18th century (Leal 1999). The definitive invasion of their land was carried out by the Chilean army in 1883, with its sequel of destruction and death, expropriation of land and the emergence of institutional and daily racism, which has become a salient feature of the cultural identity in Chile (Leal 1999).

Racism, a cultural construction of an imagined order, or 'culturalism', as Harari (2011) calls it, is not a natural condition of human beings. Racism could be considered to be one of the most profound problems that intervene in the relationship or co-existence between modernity and identity in Chile, which confronts the 'West' and the 'Rest', which makes these categories apparently incompatible. In fact, the relationship between Chileans and Mapuches continues to be highly conflictive. However, another trajectory of modernity may be unfolded, which could consider the development of intercultural practices to recognize the right of indigenous peoples to their self-determination, recognition of them as a people and the recovery of its expropriated land. That would make co-existence possible. However,

3 Mapuche are the main and largest indigenous people who inhabited what is now Chile and Argentina. Mapuche, in its Mapudungung language means 'people who belongs and whose origin is the land', Mapu: land Che: people (Leal 1999).

4 Hacienda refers to the largest land property which constituted the basis of the latifundia, from the colonial period. Its origin is feudal, from what is now Spain, specifically, Andalucia, a mode of production which reproduced servile relations in the colony. This form of ownership was possible due to the encomenderos (Catholic conquerors), who had to take care and manage the kingdom's posesions in the colonies. COntrary to this, they stole the Crown's land, which had to remain in America under the rule of the feudal dispositive known as Encomienda. It was the new social relation of production in Mapuche land. Through encomienda, the monarchy would take possesion of all land with its indigenes inside, who were called inquilinos (serfs). Thus, the encomenderos became powerful landowners who inaugurated the private ownership of land but keeping servile relatons within it, resembling the Spanish señorios (scattered fiefdoms) (Leal 1999). 
this new trajectory would require a plurinational and multicultural state, not a mono-cultural one as it is today. A new Constitutional Chart must consider it.

Unfortunately, what prevails is the legacy of pre-modern traditions from colonization and republican regimes: the 'esensialist' conception of identity that reproduces racism. Moreover, the racist cultural tradition against Mapuches and migrants are embedded in class relations. A perspective of 'historical construction' of identity — which understands identity as continuity and change-should become predominant in order to conceive identities by differentiation not by opposition (Leal 2019). The extreme right does not accept this type of change; it is one of its flags to defend 'tradition'. This is one of the ways that fascist populist discourses arise.

\section{Class and State Formation: Brief Stories of the 'Right' and the 'Left'}

Regarding state and political formations from 16th century until now, contemporary politics still retains features of feudal heritage, such as the influence of Christianity, the servile relations forged during more than 500 hundred years with Mapuche society, and between the latter and the capitalist Republic. Authoritarian features that would later be adopted in fascism, began early to emerge, above all, during the invasion and occupation of Walmapu (Mapuche land).

From these articulations, the Republican state emerged in the second decade of the 19th century, in which authoritarian regimes and then nascent democracy have led to a society in which class contradictions, patriarchy and racism have been predominant. The formation of the labor movement early in the first decade of the 20th century and later the women's movement, forged-and were a result too- of the rise of the left, which constituted the political opposition to the right. The latter had been born with the Republic in the previous century, in its conservative and liberal currents, resembling European political developments. A right wing which was and still is very attached to patriarchy, Catholicism and now, some of them, to the protestant Church.

To briefly and politically characterize the two previous centuries, it is useful to highlight that all Chilean Presidents during the 19th century were aristocratic, Catholics, patriarcal and landowner men. In the 20th century, the majority of the Presidents served the interests of the capitalist class, with notable exceptions being Salvador Allende (1970-1973) and Pedro Aguirre Cerda (1938-1941). All were male (Leal 1999).

This combination between feudal and capitalist traditions in the politics of the right have provided an authoritarian and conservative seal to Chilean politics. Right liberals attempted to moderate it, in periods in which hegemony was not in crisis. However, when the ruling class felt threatened by the people, its unity became monolithic and its class identity was reinforced. Therefore, when the Marxist Salvador Allende won the presidential election in 1970, leading a left coalition in which the Communist and Socialist parties formed the strategic axis of the alliance, and a Left National Trade Union was leading social movements, the right became fascist, because understood that the 'every day' class struggle had passed over to 'class war' (Miliband 1973). Allende's dream of a 'Chilean way toward Socialism', within a democratic framework, was violently interrupted by the military coup led by the Chilean and USA ruling classes ${ }^{5}$ (Miliband 1973).

Once the dictatorship came to power, structural changes were put in place, in order to increase levels of capital accumulation. Then, the Chilean neoliberals, advised by Friedrich Hayek and Milton Friedman, inaugurated a new epoch for capitalism in Chile and later, in the West. Three main concepts from Hayek's political philosophy can be identified as the theoretical grounds for the right's reactionary response. These intertwined concepts were individual freedom, catallaxy and social peace, which supported three main economic measures: liberalization of the market, deregulation of labor and

5 The author was an underground militant of the Left, political activist and organiser, for eleven years under the dictatorship in Chile (1980-1991). 
privatization of national industries and services. The new ideological and economic model replaced the 'import substitution economy' (Leal 2010).

The neoliberal strategy was to maximize the liberalization of the market; in consequence, the internal market was expected to reach a zero tariff for foreign commodities and goods. Meawhile, the privatization of industries and services contributed to develop an externally oriented economy. All of these policies were executed in the context of highly interventionist labor relations, in which trade unions were repressed and then forbidden. The reformulation of Chilean capitalism also required changing the role of the state, from a welfare to a subsidiary state. The minimization of the state meant the radical variation of the ownership and management of the economy, from 70 percent prior to the coup, to less than 30 percent after the coup, which involved the expropiation of most of strategic public enterprises (except for copper) by capital. Thus, the supervision and regulation of most of the economy, was in private hands under a fascist order.

Subsequently, neoliberalism's main goal was economic growth and from this, modernization, higher level of internal consumption and the increase of capital accumulation. This was supposed to mean the defeat of poverty, becoming the 'Jaguar' of Latin America' (Leal 2005). However, October $18^{\prime} \mathrm{s}$ (2019) rebellion, revealed that the extent to which that dream had not been realized. From this social movement, a plebiscite on 25 October 2020, would decide whether neoliberalism in Chile was to continue unabated.

The neoliberal right alliance in government has lost, to a great extent, its political hegemony and it is possible that the neoliberal order will be institutionally overcome, which would produce deep transformations in all areas of society. An immediate rise of the extreme right in Chile is not in the agenda in 2020, though this does not mean that the right has been defeated. The advance of the anti-neoliberal sectors could lead to an extreme polarization of class conflict, as it happened when Allende won the elections. Paradoxically, liberal democracy, the regime that Allende chose to build socialism, was shut it down by the 'champions' of that model, the right, which did not hesitate to replace it by a gruesome state terrorism. With the anti-neoliberal opposition winning the plebiscite to replace Pinochet's Constitution and to move to a 'Constitutional Convention', this sector advances to dismantle the neoliberal system from the core of institutionality. The hurt fascists could react violently, if the right's hegemony were defeated by a counter-hegemonic Constitutional Charter. A fascist military coup or a civil war may be alternatives to protect and preserve capitalist class interests.

\section{Is the Rise of the Extreme Right Really Global?}

\section{Populism in Latin America}

Let us now consider the Latin American traditional populist legacy and its likely re-emergence in the present rise of the far right. Populism has been frequently used to account for the rise of the right or the left. Populism, either of the right or the left, could be defined as "'a political position that supports the people against the elite', in consequence, presently, this could apply "to almost any movement or political party" (Löwy 2019, p. 1). This could be confusing but need not be incomprehensible.

Germani (in Figueroa 2019, p. 1) equated populism to demagogic and authoritarian regimes that degraded political institutions. The reverse arguments pointed out that populist regimes fought to achieve certain levels of social integration and to increase state functions to face Latin American underdevelopment (Fernández cited in Figueroa 2019, p. 1). To these versions, a critical perspective of the classic anti-populist views was provided by Ernesto Laclau, who theoretically justified populism as "[a] legitimate way ... of building the political link" (Laclau cited in Figueroa 2019, p. 1).

Regarding Laclau's point of view, in fact populism has had two known experiences in Latin America, which developed a strong political link between masses and nations' institutions. These movements were led by Getulio Vargas in Brazil and Juan Domingo Perón in Argentina, from the 1930s to the 1960s. Both were charismatic leaders, ex-Army officers who became skillful politicians. Peronismo was both a movement and later the most influential party with an eclectic characteristic of 
being attached to social grassroots ranging from the left to the right. Thus, populism, in this case, built a political link and it was a tool which broke-to some extent-the privilege of landowners' oligarchy, which brought about a relative economic independence for some Latin American countries (Figueroa 2019, p. 2).

However, Latin American populism did not renew its initial credentials as a builder of political links, and thus it became decadent. Certainly, these movements could not overcome underdevelopment nor achieve structural social changes because, most of them, while apparently leftist in their demands, did not attempt to build strong class politics and social links which would provide class identity and a coherent theoretical basis for a revolutionary process. They were not really utopian left parties.

In addition, populism in Latin America was very attached to tradition, to premodern values. Populist leaders were well known for being, most of them, Catholics, machistas, nationalists, chauvinists, racist and homophobic men. A traditional cultural burden of servile relations was inherited from the 'West', reproduced by colonizers in the feudal dispositive known as encomienda (Leal 1999).

Thus, a negative image of populist movement was increasing, regarded as an instrument of ambitious charismatic leaders, full of explosive rethoric against the privilege of oligarchy but, without really challenging the capitalist order. However, that negative image of Latin American populism was eventually to change; the assumption that populism had vanished forever was not correct. Bolsonaro, elected President of the largest country of Latin America, combines all the characteristics of the populist leader previously described. Conjugating them, we get almost the perfect picture of a fascist leader. We could have a fascist leader with even fewer characteristic features than these, as Eco comments (2019, p. 6). Populism may be a feature of fascism, but the two are not synonymous.

To assess the current conjuncture, although the right has won some elections in Latin America, it does not mean that the far right has reached significant power. In South America, the only case closer to fascism is that represented by Bolsonaro (Akram 2018). The case of Brazil is important because of its radicality and its relevance for the world economy and Latin American politics. Bolsonaro's victory represents a new right-wing trend with an authoritarian and populist profile, anchored in a strong relationship between the army, the evangelical church, and fascist sectors of Brazilian society. Brazil represents one case and, as Löwy (2019) comments, the far-right have their own features in each country, a point made also by Youngs (2018).

In some nations the scapegoat (or the enemy) is Muslim and/or immigrants; in some cases xenophobic nationalism and rationalism prevail; in others such as some Muslim countries, religious minorities (Christians, Jews, Yazidis); in other places religious fundamentalism; or hatred for feminism, the Left and homosexuals (Löwy 2019, p. 1). However, there are some common characteristics for the majority, if not all: authoritarianism, fundamentalist nationalism, religious or ethnic (racist) intolerance, police/military violence as the only response to social problem and crime (Löwy 2019, p. 1).

These political and social phenomena are being characterized as fascist or semi-fascist. However, given that several expressions of fascism that have sprouted, its rise will be focused below on Eco's reflection about Ur-fascism (Eco 2020, p. 6).

Recapping, the far-right ascent is happening. Löwy's (2019) arguments are convincing enough about the increasing influence of far right, and I would say, of fascism:

In recent years, the reactionary, authoritarian and/or fascist extreme right wing has been in the ascendant all over the world: it already governs half of the world's countries. Among the best-known examples are: Trump (United States), Modi (India), Orbán (Hungary), Erdoğan (Turkey), Daesh (Islamic State), Salvini (Italy), Duterte (Philippines), and now Bolsonaro (Brazil). But in several other countries we have governments close to this trend, even if they do not have such an explicit definition: Russia (Putin), Israel (Netanyahu), Japan (Shinzō Abe), Austria, Poland, Burma, Colombia and so on. In fact, the distinction between these two groups is completely relative.

Given this reality, the question is why and how this rise is happening. Let us, then, review some hypotheses. 
The first hypothesis attributes the rise of the far-right to migratory flows. However, the far-right is growing in countries such as Brazil and India, where migration is not an issue to the same extent.

The second cause of a flourishing right is capitalist globalization and cultural homogenization, leading to intolerant nationalism and ethnic conflicts, since, "[t]he more nations lose their economic power, the more the immense glory of the nation is proclaimed 'above all'" (Löwy 2019, p. 2).

A third hypothesis would come from the financial crisis of capitalism. The 2008 crisis caused economic depression, unemployment and rising social marginalization through austerity. This factor could account for Trump or Bolsonaro victories, but this was not a real factor in rich countries of Europe, such as Switzerland and Austria, in which the far right became powerful. In countries more affected by the crisis, such as Spain and Portugal, the left and the center-left are hegemonic (Löwy 2019, p. 3).

The fourth postulate for this rise of the extreme right is that it happened in countries in which neoliberalism has been dominant since the 1980s, combined with the crisis of the left due to the collapse of Eastern European Socialism in 1991.

The fifth has to do with the rise of populism, which would be a key factor, but not the main issue in the rise of the far right and the threat to liberal democracy. The assumption that populism is the reason of the rise of the far right legitimates it, voluntarily or involuntarily, making it more acceptable. Who is not for the people against the elite? (Löwy 2019, p. 1). Certainly, populism is masking problematic phenomena such as the 'far right', 'machism', 'racism' and 'xenophobia', among others, as Löwy claims. However, what is ideologically being concealing behind the term 'populism', is the most dangerous and problematic issue, fascism.

Yascha Mounk's concerns about populism as a crucial factor for the decomposition of the two components of liberal democracy is understandable (Mounk 2018, p. 7). This would be caused by 'far right or illiberal populism' which is tearing apart the apparently harmonious relationship between liberalism and democracy, "giving rise to 'illiberal democracy' on the one side, and 'undemocratic liberalism', on the other" (Mounk 2018, p. 20). However, Mounk confusion or mistake would reside (apart of his naiveness with respect to the 'harmony' between liberalism and democracy), in that he does not identify, and therefore deal with, the crucial phenomenon of fascism, generated by liberalism in crisis, since liberalism ${ }^{6}$ stresses capitalist accumulation, not democracy (see Borón 2019; Bobbio 1984), and capitalism is "structurally antithetic in respect to democracy" (Meiksins Wood 2006, p. 396).

In tracing the emergence of fascism, it is instructive to consider Eco's perspective on it. Umberto Eco asks how fascism became synecdoche ${ }^{7}$, a term which can be used for different totalitarian movements. This does not mean that fascism was the matrix containing all the elements of any further form of totalitarism. In fact, "fascism did not have an essence, this was a confusing totalitarism, a collage of different philosophical and political ideas, a hive of contradictions" (Eco 2020, p. 4). He comments that "the Italian fascist party was born bragging to bring a new revolutionary order, but it was financed by landoweners", who expected the contrary. Eco's point is that "fascism was out of place philosophicaly, but emotionally, it was firmly attached to certain archetypal foundations" (Eco 2020, p. 4).

The second point, following the arguments of the first, is that fascism would be a kind of 'game' which can be played in many ways, and the game's name does not change:

The term "fascism" fits everything because it is possible to eliminate one or more aspects of a fascist regime, and we can always recognize it as fascist. Take away imperialism from fascism and you will get Franco or Salazar; take away colonialism and you will get Balkan fascism. Add radical anti-capitalism to Italian fascism and you have Ezra Pound. Add to that the cult of Celtic mythology and Grail mysticism ... and you get one of the most respected fascist gurus: Julius Evola.

6 Neoliberals, according to Borón (2019), have gone farer than their historical mentors, like Locke (1963) and its classical piece, The Second Treatise on Government.

7 Synecdoche is a figure of speech in which a part is made to represent the whole or viceversa. 


\section{(Eco 2020)}

Beyond the apparent confusion of these multiple fascisms, Eco elaborated a list of typical features of what he called 'Ur-Fascism' or 'eternal fascism'. "Such characteristics cannot be framed in a system; many contradict eachother, and are typical of other forms of despotism or fanaticism, but it is enough that one of them is present to coagulate a fascist" (Eco 2020, p. 6).

The first one is the cult of tradition. Traditionalism is older than fascism. Traditionalism expressed a syncretic culture, but not reduced to the meaning of the encounter of different beliefs or practices. For this current,

all original messages carry a primitive germ of wisdom and, when they seem to say different or incompatible things, they do so only because they all allude, allegorically, to some primitive truth. As a result of this, the truth has already been announced once for all, the only thing we can do is continue to interpret its dark message, there can no longer be advance of knowledge.

(Eco 2020, p. 7)

Irrationalism would be a second feature of Ur-fascism. It is known that traditionalism rejects modernism. Curiously, fascists and nazis loved technology, while traditionalists reject it because this would deny spiritual traditional values. However, the Nazis' pride in their industrial development, would be only a superficial celebration of modernity. Their ideology was strongly based on 'blood and soil'. The camouflage of its rejection of modernity was in condemning capitalist-American style of life. "Enlightenment and the age of reason would be the origins of the modern depravity" (Eco 2020, p. 7).

As logical thought would indicate, irrationalism would depend on the 'action for action's sake'. Action can happen prior or even without reflection at all, and "thought would be a form of castration". Thus, culture is suspicious for its identification with critical attitudes. ... [I]ntellectual fascists accuse the modern culture and liberal intelligentsia of having abandoned traditional values (Eco 2020, p. 8).

In additon to the cult of action, Eco warns that critical thinking is unacceptable for syncretism. A critical attitude implies distinction and this rational capacity would be indicative of modernity. The modern culture understands disagreement as an instrument of progress toward knowledge. Conversely, for Ur-Fascism, disagreement is treason. At the same time, disagreement would mean diversity. "Ur-Fascism grows exploiting and exacerbating the natural fear of difference. Then the fascist first call is against the intruders. Thus, fascism is racist by definition" (Eco 2020, p. 8).

Following the previous two features, fascism also arises from social or individual frustration:

This is why one of the typical characteristics of historical fascism has been the call to the frustrated middle classes, a class suffering from some economic crisis or political humiliation, frightened by the pressure of the subaltern social groups. In our age, when the old "proletarians" are turning into the petty bourgeoisie (and the lumpen are excluded from the political scene), fascism will find its audience in this new majority.

(Eco 2020, p. 8)

In addition, Eco comments that to those who lack cultural identity, Ur-Fascism tells them that "their most precious privilege ... is to have been born in the same country. This is the origin of nationalism. The enemies are the only ones who can offer an identity to the nation. The henchmen must feel under siege" (Eco 2020, p. 9). Then, the easiest way for a plot to emerge is to appeal to xenophobia. Presently, and because of the exacerbation of 'the fear of others' by the Chilean government, the new immigration law is being decided between a 'restrictive and coercive migration perspective' (from the far-right), which is in acute tension with the human rights-based migration approach (Ceriani Cernadas 2017, p. 6).

For Ur-Fascist there is no struggle for life, rather, life for struggle. Pacifism is then trafficking with the enemy. It is bad because life is a permanent war. "Since the enemies must be defeated, there must be a final battle, which will result in gaining ... world control. Such a final solution implies a 
successive age of peace ... that contradicts the principle of permanent war. No fascist leader has ever managed to resolve this contradiction" (Eco 2020, p. 9).

It should be added that it is indispensable to address something which is typical of all reactionary ideology, the elitism, an aristocratic and militarist elitism rooted in feudal, monarchical and pre-modern values, which despises weak people, such as Chilean elitism. Then Ur-Fascism only can advocate for a 'popular elitism':

Every citizen belongs to the best people in the world, party members are the best citizens, every citizen can (or should) become a party member. But there can be no patricians without commoners. He also knows that his strength is based on the weakness of the masses, who need and deserve a ruler. Since the group is organized ... according to a military model, every subordinate leader despises his subordinates, and each of them despises his inferiors. All of this reinforces the sense of mass elitism.

(Eco 2020, p. 9)

Machismo, the next feature. Fascists expect that since "both permanent warfare and heroism are difficult games, they transfer their will to power to sexual matters ... the origin of machismo, which implies disdain for women and an intolerant condemnation of [non-common] sexual mores, from chastity to homosexuality" (Eco 2020, p. 9).

Qualitative populism: in a democracy, as Mounk argues (2018), citizens enjoy individual rights. Eco (2020, p. 9) adds that, however, all citizens are only endowed with a political impact from a quantitative point of view - the decisions of the majority are followed.

For Ur-Fascism, individuals as individuals have no rights, and the People is conceived as a quality, a monolithic entity that expresses the common will. Since no number of human beings can possess a common will, the leader pretends to be its interpreter. Having lost the power to delegate, citizens do not act; they are called only to play the role of the People. In this way, the people is only a theatrical fiction.

Eco adds, as a projection of the present that "to give a good example of qualitative populism, we no longer need Piazza Venezia or the Nuremberg Stadium. In our future, a qualitative television or Internet populism is emerging, in which the emotional response of a selected group of citizens can be presented or accepted as the Voice of the People" (Eco 2020, p. 10).

This list of Eco's of characteristics of fascism is a useful account of the diversity of contents of fascism. This plurality has led some authors, as Monge comments, to call it 'fascisms' (Monge 2008, p. 267). Certainly, not all populist movements can be called fascist but, this plurality of fascist formations have led to the argument that "fascisms lack a conceptually coherent theory" (Monge 2008, p. 268). However, one of the main historians of fascism, Ernst Nolte, warns that such conception undervalues the eclectic nature of fascist ideologies. In fact, this eclecticism, which allows fascism to simultaneously incorporate elements of anti-capitalist and anti-socialist character in its discourse, explains, to a great extent, the roots that fascism grows as a movement of masses (cited in Monge 2008, p. 268). Lastly, it is worthy to note that to discuss the meanings of fascism is also to discuss modernity, in relation to its possibilites and limits (Monge 2008, p. 267).

It seems that it is not by chance that fascism is being unfolded in different latitudes and, at the same time, neoliberalism, postmodern and pre-modern beliefs are merging to inform these movements. Larraín and Habermas provide timely reflections in this respect. Larraín characterizes neoliberalism as a conception of:

[T] he economic and social relations of people based on a spontaneous order of the market (as defined by Hayek) that opposes planning state economy, which uses democracy as a means to achieve the end (the market) and, furthermore, eschews belief in social justice and rejects the idea of the common good. It has nothing in common with classical and social liberalism, nor with the free market economy".

(Larraín 2005, p. 71)

Larraín adds to this something crucial: 
Neoliberalism would have a relationship, on the other hand, with postmodernism, while both would be anti-modern traditions that criticize enlightened reason, considering that it does not account for the 'spontaneous' situation that must govern societies - according to neoliberals-and does not represent at the same time the fragmentation and chaos that is characteristic, according to postmodernists, of societies today. Consequently, they could be defined as essentialists, which links them to "baroque modernity", the one so defended by Morandé in Chile. In other words, "postmodernism has become the fundamental logic of neoliberalism".

(Larraín 2005, p. 71)

Consistent with this is Habermas's earlier observation from the cultural field (Habermas 1988, p. 8). He notes:

fears that anti-modernity ideas, along with an added touch of pre-modernity, are becoming popular in alternative culture circles. When one observes the transformations of consciousness within political parties in Germany, a new ideological change (Tendenzwende) is visible. And this is the alliance of postmodernists with premodernists. It seems to me that there is no specific party that monopolizes the outrage against the intellectuals and the position of neoconservatism.

Thus, we see arising over this period theoretical perspectives assisting, voluntarily or involuntarily, fascist discourse and the formation of fascist movements. These work to enhance capital's profitability through neoliberal ideology, sharpening the class contradiction between capital and labor, also expressed in an acute tension between liberalism and democracy. Hayek believed that the main concern for neoliberals was to increase profit: individual freedom, catallaxy and social peace were the means to reach highest levels of profitability. Therefore, the main concern was not the regime hosting capitalism but what limits it. For that, social peace had to be guaranteed. Whether this is achieved under a dictatorship or a democracy, does not matter (Leal 2010).

Chile has been one of the better examples of that. Neoliberalism, as an ideology supporting the model of an accelerated capital accumulation, worked well in both regimes, until the outbreak of class struggle in both periods. These rebellions revealed the violent and unjust character of this model and unmasked its ideology. The 'social peace' and profit achieved through state terrorism (dictatorship) and later, by consent through ideology (democracy), was not to the benefit of the people but of the rich minority. Now, the face of fascism reappears in this country, aiming to defeat the uprise of class struggle that broke out on 18 October 2019.

\section{18 October 2019²: Social Outbreak, The Class Struggle in Chile Emerges Once Again}

In October 2019, Chilean President Sebastián Piñera told the Financial Times:

Look at Latin America. Argentina and Paraguay are in recession, Mexico and Brazil in stagnation, Peru and Ecuador in deep political crisis and in this context Chile looks like an oasis because we have stable democracy, the economy is growing, we are creating jobs, we are improving salaries and we are keeping macroeconomic balance... Is it easy? No, it's not. But it's worth fighting for.

"[This interview] was published on October 17, Chile's capital of Santiago was in flames. Populist anger, the wolf Piñera had devoted his presidency to keeping at bay, was now at the door" (Pons et al. 2020, p. 1).

When the contradiction between capital and labor reaches an unsustainable tension due to the sharpening activity of one of its poles, in this case that of capital—expressed in an accelerated process of accumulation, at the expense of the precariousness of the pole of labor-the contradiction becomes

8 From (Leal 2020, pp. 18-36). 
explicit on the surface in the form of class struggle, as the pole of labor is also activated through a practice that ends up completely revealing the contradiction that lay hidden.

The 'plebeian' irruption of October embodied a new subjectivity or subjectivities to those prior to 18/10 (Leal 2020, p. 19). Expressions that have unleashed liberating political, social and cultural practices, new social movements together with more traditional ones, such as 'the theses' from the feminist movement; the trade unions, the student movement, social network activities for communications and coordination; the participation of pensioners in all marches; the voice of girls and boys for their rights and against repression; the movement for the defense of human rights; the councils and neighborhood assemblies; the brave and stubborn resistance of the 'front line'; and the relevance of the Mapuche cause in this framework of popular uprising. In short, the social, political, and cultural protest of millions of people has reconstituted the social fabric and politicized the people. There has been no better school for civic education than the street, in this multifaceted class struggle, today with new, fresh demonstrations that have renewed the spirit and subjectivity of our battered society. The Right was and still is cornered by the people.

Thus, the 'whirlwind' of this popular rebellion has demonstrated that social class, gender, political and cultural relations do not exist separately, but rather intertwined, form and reform each other, including previous and current generations of Chileans who discovered the deception, who have, in this way, reconstituted the social movements so severely damaged by neoliberalism (Leal 2020). Damaged not by 30 pesos rise in the price of the train ticket but by more than 30 years of social injustice and aggression to people's dignity. That would be the meaning of the great expression 'Chile woke up forever', captured on the walls of the streets throughout the country (Leal 2020, p. 20). Accordingly, we can argue that neoliberalism has been an ideology as a theoretical formulation and cultural experience, on the one hand; and on the other, as a concrete historical experience, in which it has been anchored to important changes in the forms that the State and development models have taken (Ruiz 2019, p. 12). In this way, the process of concentration and accumulation of capital was radicalized, which today has entered into a deep, perhaps terminal crisis that would also impact the rise of fascism in the world.

As noted previously, in the rapid unfolding of this crisis, multifaceted social mobilization played a key role, clearly identifying the causes of the current crisis, and with them, its contradictions and the serious social consequences that affect most of the population. In this framework, the government's program ended on 18 October. The President answered by repressing and violating the human rights of thousands of Chileans, further deepening the grave in which his neoliberal creed was being buried.

\section{The Class Struggle Shakes Neoliberal Ideology and the Dominant Class}

We can affirm without doubt that the rebellion of millions of people was the cause and at the same time the 'awakening' of a social, class, gender, intercultural and political consciousness, which has allowed the people to appreciate the world of appearances that, like a reality show, the right had built. Carlos Ruiz observes that "neoliberalism [has been] so present in our daily lives, in all its corners that we did not even [register] it, as an ideology, as if it were a natural force" (Ruiz 2019, p. 11).

Certainly, if anything crucial was revealed by the October rebellion, it was that "this ideology had reshaped individuals and society at their will, until becoming indistinguishable from their habits and practices" (Ruiz 2019, p. 11). In other words, until the moment of the social explosion, our practices were rather limited, in the sense that we did not realize what was really happening, the contradictions that were taking place and how they affected us ${ }^{9}$.

9 In his critique of German ideology, Marx points out that his supporters are wrong in explaining practice from the formation of ideas rather than explaining ideas from practice ... the importance of practice for the production of ideas derives from the most basic premise that social reality itself should be conceived as practice (Larraín 1983, p. 19) ... Ideology then refers to a limited material practice, which generates ideas that distort social contradictions in the interest of the ruling class (Larraín 1983, p. 27) ... [Ultimately], appearances are reproduced in consciousness, not as an inevitable result, but as a result of a 'limited material mode of activity' ... [However] in conceiving the possibility of a revolutionary practice, Marx argues that those appearances can be overcome. [In this sense] it is important to emphasize that, for Marx, the possibility of 
The protest then was an eloquent demonstration of overcoming these limitations by expressing the rise of class, gender and intercultural consciousness, among many others, which speaks to the emergence of various subjectivities, as previously noted, that were in the process of development, which finally broke the siege of appearances imposed by neoliberalism for more than 40 years and extinguished the few voices of fascist sectors. It seems then that in the way of appreciating what has happened in Chile in its recent history,

... neoliberalism would have been born with the deliberate purpose of reorganizing human life, including the way in which society deliberates about itself. Its obstinacy in relocating the market to the center of the human condition is opposed to politics as a space for rational deliberation. It is a doctrine that bursts forth seeking to impose a conception of society and of the individual where competition becomes the basic form of social relations, the hallmark of the human condition.

(Ruiz 2019, p. 11)

The right called on the opposition to subscribe two national agreements, in order to save and keep its continuity and the capitalist order. These pacts were made under the same precepts in which the ruling class has exercised its power, those of neoliberal ideology. As Larraín argues, in expounding Marx's notion of ideology:

... although it is the ruling class that identifies and benefits from the effect of ideology in the capital generation process, the distortion that ideology carries with it, it is not the exclusive heritage of any particular class, although ideology serves only the interests of the ruling class. That all classes can produce ideology is the consequence of the universality of the limited mode of activity. That ideology can only serve the interests of the ruling class is the objective result of the fact that the denial of the concealment of contradictions plays a greater role in the reproduction of those contradictions: it is only through the reproduction of [them] that the ruling class can reproduce itself as such. In that sense, the reproduction of contradictions can only serve the interests of [that] class. So this means that the role of ideology is not defined by its class origin, but by the objective cover-up of contradictions.

(Larraín 1983, pp. 28-29)

The mirage of the 'Jaguar of America' (Leal 2005) highlighted the apparent advent of modernity, access to consumer goods, prosperity, and the development that we would all enjoy. These images did not allow us to see the dispossession that occurred through the privatization of industries and services, labor deregulation and market liberalization, pillars of this extreme form of accumulation (Martin and Schumann 1998). In simple terms, the largest looting we can remember!

In this way, we came to have a country auctioned off to the highest bidder; its state reduced to a poor subsidiary role; low wages for most; unworthy pensions for the elderly; low-quality commercialized education, the result of the destruction and abandonment of public education; public health unprotected and precarious; the Mapuche people discriminated against, repressed and plunged into extreme poverty; women besieged by male rapists personified in the state and in hegemonic male power, which continues to harass and postpone them, assigning them a role as reproducers of the social class and gender division of labor. What to say about natural resources, which have been delivered to the ruthless exploitation of transnational companies; and the scarce freedom of information due to monopoly control of the media. All these processes constitute only the most visible of the problems that have existed until now, and have played in favor of the accumulation of wealth of the one percent of the population to the detriment of the majority, precarious and socially disintegrated.

overcoming ideology would reside in revolutionary practice, and not merely in the development of the theory of science. (Larraín 1983, p. 34). 


\section{High School Students Jump the Turnstyle}

The 'turnstyle jump' in Santiago's Metropolitan train system would reveal the dark reality of Chile as Latin American 'jaguar'. In other words, the veil was lifted in which neoliberal ideology had kept us in a disturbing passivity, only shaken by sectoral movements such as education, which raised the alert that something was happening.

However, the besieged ruling class still retains sufficient power to bring its head to the surface. Despite their stubborn resistance, the ruling class, being cornered and unable to react, they had to accept what they never would have even imagined, the popular demand for a new Constitution. A plebiscite was achieved by people's struggle, a plebiscite to decide between two alternatives, the old or a new Constitution, which includes the Constituent Assembly (but suspiciously with another name) and their own. However, the warning is that the right will demand the current quorum of $2 / 3$ to approve articles and laws to enact. In other words, if this figure is not achieved, 34 percent worth the same as 66. This means that although the right yielded in these demands for the change of the Constitution, it will continue to have veto power (Leal 2020, p. 22).

Neoliberal ideology operates at least through the three interconnected planes that established the principles enunciated by Hayek: individual freedom, catallaxy and social peace. These three ingredients begin "[to] disrupt the general interest with the particular interest [by proposing] that the pursuit of self-interest in society is the main lever of innovation and progress" (Ruiz 2019, p. 12). Individual freedom allows entrepreneurship in that we all start competing equally in the confines of the market. It is there where, by virtue of competition, some would advance more than others, thus generating an inevitable inequality, "in this way, capitalism would be dynamic because it is unequal, and efforts to attenuate that inequality—-to promote equality - entail a limitation to individual initiative which in this creed, is the great source of energy to achieve the material satisfaction of society" (Ruiz 2019, p. 12). Accordingly, in neoliberal ideology there are 'winners and losers' engaged in an apparent 'good' fight, Social groups do not confront each other as classes; they are only socioeconomic strata (Ruiz 2019, p. 12). In this model there is no fundamental conflict, no class contradiction. Classes in this view of capitalism have ceased to exist, or never have existed. All this means that the rich become so by their virtues, not by their privileges, and the poor become losers for their lack of initiative, for which they might as well blame themselves.

Neoliberalism is an ideology ${ }^{10}$, not only because it intervenes sharply in society in the above-mentioned form of appearances that become habits, customs, and beliefs, but because it is inserted into concrete human activity, (unlike other theories covered by cobwebs in academic libraries). That is why neoliberalism has been deeply rooted in people, which "becomes mass culture, which Antonio Gramsci points to as common sense" (Ruiz 2019, p. 12). This distortion shown by neoliberal ideology is manifested, in these times, in an excessive emphasis on the individual, which has, as a consequence a fragmentation and social disintegration so profound that it has come to be expressed in a true 'epidemic of loneliness', to such an extent that it has become a subject of study (Ruiz 2019, p. 12).

Lastly, when ideology does not manage to obfuscate class interests and obtain consent, and there is an uprising of the people, fascism enters the scene. After 18 October, a criminal repression was activated by the Chilean state. According to the second Human Rights Watch Report, 25 people were killed during the suppression of this uprising; 11,500 were arrested in this period; 1600 protesters were left with various injuries inflicted by the police; 220 , at least, were seriously wounded in their faces, in their eyes; 2 people were completely blind; 16 lost the sight of one of their eyes; 34 people still do not know if they will lose the vision of one or both eyes. To these are added torture and rape of men and women detained by the police (Radio Bío-Bío 2019).

10 About the concept of ideology and its crucial function for capitalist hegemony in USA and in the World, see (Chomsky 1988), About Power and Ideology, Conference in Managua 2, Visor Lingüística y Conocimiento, Visor Distribuciones, S. A., España. 
In short, the social outbreak changed Chile and left the Right with exiguous support in Chilean civil society. The Chilean state has shown its preparedness to resort to large-scale violence reminiscent of the Pinochet dictatorship, including killings, maiming, torture, and rape. The pandemic that succeeded the popular rebellion, has made more evident the magnitude of the social and human catastrophe that capitalism has brought to Chile and the world, in 'the West' and the 'Rest'. If ideology cannot lessen the counter-hegemony, then fascism, as in the recent past, is around the corner.

\section{Conclusions}

This essay has sought to understand the current conjuncture in Chile in the context of the rise of the global far right. It has shown how, as a response to crises of neoliberalism, we are experiencing the development of fascist formations around the world. Regarding the historical background of the unjust relationship established by the 'West' in respect to the 'Rest' (and in this case South America) during the passage from feudalism to capitalism and later, in the development and consolidation of the latter as the predominant mode of production in what bécame the social formation in Chile, there seems to be a strong tendency for fascism to emerge with a certain periodicity, in particular, during runaway activity of the pole of capital to the detriment of the pole of labor, in response to a crisis of accumulation. Diverse factors contribute to this complex phenomenon. The collapse of the challengers to American-led capitalism, the Soviet Union and Western European socialism, and the subsequent weaknesses, or almost nonexistence of a utopian left and, the decadence of social democracy, would be among these factors. In this framework, a global neoliberal ideology has marked the supremacy of capitalism and the free flux of capital, its rate of accumulation and simultaneously, augmented the precarity among subordinated classes. Furthermore, the endemic, artificial, and anachronistic relationship between liberalism and democracy has been deeply damaged, owing to the dynamic of imperatives of profitability and accumulation being privileged over the wishes of the people, this is, over democracy. In this intrincate scenario, to explore the rise and meaning of fascism has led us to examine the state and possibilities of modernity and its limits in Chile, as elsewhere in the 'Rest'. An incomplete modernity seems to be trapped, besieged by merging pressures coming from premodern esentialists conceptions and practices, on one side, and by the postmodern representation of 'chaos and fragmentation as a spontaneous social order' on the other, which has encouraged the activity of neoliberlism becoming compatible with both pre-modern and postmodern conceptions.

Also, it has been worthwhile noting that this current rise of fascisms is peculiarly lacking in coherent theory. Philosophically would seem out of place, but subjectively fascism would be firmly anchored to certain archetypal foundations. In addition, that apparent theoretical lack of coherence cannot neglect the eclectic nature of fascist ideologies, which incorporate a wide range of right and left discourses, which has enabled its roots in mass movements and its growth. Finally, it should be said that because of the contradiction between capital and labor, the acute dynamic of the pole of capital activates the contrary, to a point in which distortion, the main effect of ideology, is revealed and contradictions emerge on the surface as class struggle. This runaway activity of capital has been resisted, rejected and partialy defeated by the rebellion of October 2019 in Chile, as was shown above. The far right has backed down but, has not been defeated. The fact is that neoliberalism is in a deep, perhaps terminal crisis. The plebiscite on 25 October 2020, may have opened the way that the great alamedas will be opened', as Allende pointed out in his posthumous speech the 11 September 1973, when the Palace of Government was being bombed by the fascists. We must recognize that they are still among us.

Funding: This research received no external funding.

Conflicts of Interest: The authors declare no conflict of interest. 


\section{References}

Akram, Hassan. 2018. 'La Falsa Narrativa del Auge de la Extrema Derecha en el Mundo' (the False Narrative of the Rise of Far-Right in the World). El Descontento; Santiago, Chile. Available online: https://www.eldesconcierto.cl/2018/11/14/los-peligros-del-pesimia-la-falsa-narrativa-del-auge-dela-extrema-derecha-en-theworld/ (accessed on 27 June 2020).

Aranguiz, Santiago. 2007. Reseña: “¿América Latina Moderna? Globalización e Identidad”. (Book Review: “Modern Latin America? Globalization and identity"). Edited by Jorge Larraín. Santiago, Chile: Instituto de Historia, Pontificia Universidad Católica de Chile, vol. I, pp. 204-14.

Azocar, Oscar, Fernando Carmona, Francisco Herreros, René Leal, and Pablo Monje. 2020. Papeles de Coyuntura y Tendencias Políticas: Dos Años de Gobierno de Piñera, Levantamiento Popular y Crisis del Orden Neoliberal. (Papers on Political Conjuncture and Tendencies: Two Years of Piñera Government, Social Uprising and Crisis of the Neoliberal Order). Santiago: CLACSO, Instituto de Ciencias Alejandro Lipschutz (ICAL) and Instituto Rosa Luxemburg, Available online: http://ical.cl/wp-content/uploads/2019/10/UN-AN\%CC\%83ODE-GOBIERNO-3-1.pdf (accessed on 8 December 2020).

Azocar, Oscar, Fernando Carmona, René Leal, and Pablo Monje. 2019. Papeles de Coyuntura y Tendencias Políticas: A 10 meses del Gobierno de Piñera ¿Tiempos Mejores? Promesas Incumplidas. (Papers on Political Conjuncture and Tendencies, After 10 Months of Piñera Government Better Times? Unfulfilled Promises). Santiago: CLACSO, Instituto de Ciencias Alejandro Lipschutz (ICAL) and Instituto Rosa Luxemburg, ISBN 978-956-398-483-5. Available online: http://ical.cl/wp-content/uploads/2019/10/UN-AN\%CC\%83O-DE-GOBIERNO-3-1.pdf (accessed on 9 December 2020).

Bobbio, Norberto. 1984. El Futuro de la Democracia (The Future of Democracy). Mexico City: Fondo de Cultura Económica.

Borón, Atilio. 2019. El Hechicero de la Tribu: Mario Vargas Llosa y el Liberalismo en América Latina (The Tribe Sorcerer, Mario Vargas Llosa and Liberalism in Latin America). Mexico City: Ediciones AKAL/Inter Pares.

Ceriani Cernadas, Pablo. 2017. Inmigration Detention through the Lens of International Human Rights: Lessons from South America. In Global Detention Project, Working Paper $N^{\circ} 23$, Open Society Foundations. Edited by Michael Flynn and Mathew Flynn. Working Paper Series; Statesboro: Georgia Southern University.

Chomsky, Noam. 1988. About Power and Ideology, Conference in Managua 2. Visor Lingüística y Conocimiento. Madrid: Visor Distribuciones.

Eco, Umberto. 2020. ¿Qué es el Fascismo (What Is Fascism?). Interferencia. Available online: https://interferencia. cl/articulos/que-es-el-fascismo-segun-el-escritor-y-filosofo-umberto-ecco (accessed on 22 August 2020).

Figueroa, Fernanda. 2019. Populismo en America Latina: Getulio Vargas y Juan Domingo Perón (1930-1955): Estudio de Caso. (Populism in Latin America: Getulio Vargas and Juan Domingo Perón (1930-1955: Case Study). Available online: http://redesperonismo.org/articulo/populismo-latinoamericano-getulio-vargas-y-juandomingo-peron-1930-1955-estudio-de-casos/ (accessed on 10 October 2020).

Habermas, Jürgen. 1988. "La modernidad, un proyecto incompleto“ (Modernity, an incomplete project). In The Postmodernity. Edited by Foster Hal. Mexico: Kairós Publisher.

Hall, Stuart. 2013. Discourse and Power. Edited by Ricardo Soto Sulca. Huancayo: Melgraphic E.I.R.L.

Harari, Yuval Noah. 2011. Sapiens, A Brief History of Human Kind. London: Penguin Random House, Vintage Books.

Larraín, Jorge. 1983. Marxism and Ideology. Edited by Anthony Giddens. London: The Macmillan Press LTD.

Larraín, Jorge. 1989. Theories of Development. Cambridge: Polity Press.

Larraín, Jorge. 2005. ¿América Latina Moderna? Globalización e Identidad (Modern Latin America? Globalization and Identity). Santiago: LOM.

Leal, René. 1999. Articulation in Chile and Mapuchemapu: Gender, Class and State Formation, 1400-1900. Unpublished Ph. D. Thesis, University of Wollongong, Wollongong, New South Wales, Australia.

Leal, René. 2005. “Chile, el Jaguar y el País de los Cien Pesos” (Chile, the Jaguar and One Hundred Pesos Country). In Globalización, Identidad y Justicia Social. (Globalization, Identity and Social Justice). Edited by René Leal. Santiago: SIT-ARCIS Publisher, pp. 223-62. ISBN 956-8114-53-X.

Leal, René. 2010. Globalización: Teorías y Debates (Globalization: Theories and Debates). Revista Chilena de las Comunicaciones, Vicerrectoría Académica. Santiago: UNIACC. Available online: https://www.latindex.org/ (accessed on 8 December 2020). 
Leal, René. 2019. “El Movimiento Feminista y la Relación entre Género y Clase” (The Feminist Movement and the Relationship between Gender and Class). In Papeles de Coyuntura y Tendencias Politicas: A 10 meses del Gobierno de Piñera, ¿Tiempos Mejores? Promesas Incumplidas. (Papers on Political Conjuncture and Tendencies: After 10 Months of Piñera Government, Better Times? Unfulfilled Promises). Santiago: ICAL-CLACSO Publishers.

Leal, René. 2020. Acuerdos Nacionales por una Nueva Constitución y la paz Social: Últimos Aparatos Ideológicos de la Clase Dominante Para su Reproducción. (National Agreements for a New Constitution and for Social Peace: Ruling Class' Last Ideological Devices for Their Reproduction). Revista Alternativa. Santiago: Instituto de Ciencias Alejandro Lipschutz, pp. 18-36.

Locke, John. 1963. Two Treatises of Government. Cambridge: Cambridge University Press.

Löwy, Michael. 2019. The Far-Right, a Global Phenomenon. International Viewpoint: News and Analysis from the Fourth International. Available online: http://www.internationalviewpoint.org/spip.php?article5890 (accessed on 8 December 2020).

Martin, Hans-Peter, and Harald Schumann. 1998. The Global Trap, Globalization and the Assault on Democracy and Prosperity. London: Zed Books, Chicago: The University of Chicago Press Books.

Meiksins Wood, Ellen. 2006. State, capitalism and globalization. In Marxist Theory Today. Edited by Atilio Boron, Javier Amadeo and Sabrina González. Buenos Aires: CLACSO, p. 396.

Miliband, Ralph. 1973. The Coup in Chile (October 1973). London: The Socialist Register, pp. 451-74.

Monge, Alvaro. 2008. 'Algunas consideraciones sobre filosofía y fascismo' (Some considerations about philosophy and fascim). In Mapocho, Revista de Humanidades. Santiago: Biblioteca Nacional de Chile, pp. 267-77.

Mounk, Yascha. 2018. The People versus Democracy: Why Our Freedom is in Danger. Cambridge: Harvard University Press, USA.

Pons, Vincent, William Mullins, John Masco, Annelena Lobb, and Rafael Di Tella. 2020. Unrest in Chile: A Case Study. Boston: Harvard Business School, Harvard University Press.

Radio Bío-Bío. 2019. Report of Human Right Watch. In El Informador, News in in Radio Bio-Bio, 13.00 hours, 26 November, 2019, Chile. New York: Human Rights Watch.

Ruiz, Carlos. 2019. La Política en el Neoliberalismo: Experiencias Latinoamericanas. (Politics in Neoliberalism: Latin American Experiences). Santiago: LOM.

Youngs, Richard. 2018. Quienes Están Detrás del Auge de la Extrema Derecha en el Mundo (Who Are Behind of the Extreme Right in the World?). BBC World News. Carnegie Europe. Available online: https://www.bbc.com/mundo/noticias-internacional-46097108 (accessed on 27 June 2020).

Publisher's Note: MDPI stays neutral with regard to jurisdictional claims in published maps and institutional affiliations.

(C) 2020 by the author. Licensee MDPI, Basel, Switzerland. This article is an open access article distributed under the terms and conditions of the Creative Commons Attribution (CC BY) license (http://creativecommons.org/licenses/by/4.0/). 